\title{
pH-Driven RNA Strand Separation under Prebiotically Plausible Conditions
}

\author{
Angelica Mariani,* Claudia Bonfio, Christopher M. Johnson, and John D. Sutherland*(i) \\ MRC Laboratory of Molecular Biology, Francis Crick Avenue, Cambridge Biomedical Campus, Cambridge CB2 0QH, U.K.
}

Supporting Information

\begin{abstract}
Replication of nucleic acids in the absence of genetically encoded enzymes represents a critical process for the emergence of cellular life. Repeated separation of complementary RNA strands is required to achieve multiple cycles of chemical replication, yet thermal denaturation under plausible prebiotic conditions is impaired by the high temperatures required to separate long RNA strands and by concurrent degradation pathways, the latter accelerated by divalent metal ions. Here we show how the melting temperature of oligoribonucleotide duplexes can be tuned by changes in $\mathrm{pH}$, enabling the separation of RNA strands at moderate temperatures. At the same time, the risk of phosphodiester bond cleavage is reduced under the acid denaturation conditions herein described, both in the presence and in the absence of divalent metal ions. Through a combination of ultraviolet and circular dichroism thermal studies and gel electrophoresis, we demonstrate the relevance of geological $\mathrm{pH}$ oscillations in the context of the RNA strand separation problem. Our results reveal new insights in the field of prebiotic chemistry, supporting plausible geochemical scenarios in which non-enzymatic RNA replication might have taken place.
\end{abstract}

$\mathrm{R}$ NA, or a close variant thereof, is considered the first genetic polymer that appeared on early Earth. Recent investigations have shown how RNA mononucleotides, along with other building blocks considered necessary for life, might have chemically formed from the interplay of plausible prebiotic reaction networks in a defined geochemical setting. ${ }^{1-6}$ However, the transition from the chemistry of RNA monomers to the biology of a self-replicating system has been challenged by the many problems encountered with multiple cycles of non-enzymatic RNA replication. ${ }^{7}$ Chemical copying of RNA oligonucleotides might have resulted either from the templated polymerization of activated ribonucleotides $^{8-10}$ or from the templated ligation of shorter RNA fragments. ${ }^{11}$ In both cases, a dead-end, double-stranded product is generated, and separation of the template and daughter strand is required prior to a new round of replication. The plausibility of thermal denaturation of RNA is hampered by the high melting temperature of oligoribonucleotides, to the point that duplexes of $>30 \mathrm{bp}$ are considered impossible to melt under plausible prebiotic conditions. ${ }^{7}$ Concurrent RNA degradation is known to occur at elevated temperatures and is made worse by the presence of divalent metal ions ${ }^{12}$ (such as
$\mathrm{Mg}^{2+}$ ), which are required as catalysts during RNA replication. From the observation that unnatural $2^{\prime}, 5^{\prime}$-linkages destabilize RNA duplexes, ${ }^{13}$ Szostak and co-workers suggested backbone heterogeneity as a possible solution to the strand separation problem. ${ }^{14}$ However, the instability of such linkages in a duplex environment ${ }^{15,16}$ and the need to separate strands of native RNA prompted us to interrogate plausible geochemical scenarios on early Earth in the search for additional solutions.

Our curiosity was piqued by a report describing the different $\mathrm{pH}$ values of $\mathrm{NaCl}$ solutions at the eutectic point and after thawing, in principle leading to $\mathrm{pH}$ variations of $>5$ units between the two phases. ${ }^{17}$ More recently, heat fluxes have been shown to support the establishment of stable $\mathrm{pH}$ gradients in a closed system, such as those that could have occurred inside rock pores on primordial Earth. ${ }^{18}$ In both cases, geological heating and freezing could have acted as natural energy sources/sinks to support the development of local $\mathrm{pH}$ gradients, thus opening the possibility of repetitive $\mathrm{pH}$ oscillations. As DNA is known to undergo reversible acid denaturation $^{19-22}$ (presumably through protonation of GC base pairs and consequent formation of Hoogsteen base pairing), the melting temperature of RNA oligonucleotides is likely to be similarly influenced by the $\mathrm{pH}$ of the solution. ${ }^{23,24}$ Hence, we envisioned that natural $\mathrm{pH}$ fluctuations might have supported cycles of RNA strand separation and reannealing, circumventing the need for high temperatures and the undesirable degradation thereby incurred.

Here we report our investigation of the $\mathrm{pH}$ dependence of the melting temperature and stability of different RNA oligonucleotides and the relevance of such results in the context of the prebiotic RNA strand separation problem.

Our study initially focused on outlining the effect of acidic $\mathrm{pH}$ values on the temperature at which $50 \%$ of a 13 mer RNA duplex is denatured [melting point $\left(T_{\mathrm{m}}\right)$ ]. Ultraviolet (UV) thermal melting curves were measured by incubating stoichiometric amounts of oligonucleotide $\mathbf{1 a}$ and its complementary strand $\mathbf{1 b}$ [duplex 1, GC content of $53.8 \%$ (Table S1)] at different $\mathrm{pH}$ values (3.1-7.1) and monitoring the variation of their absorbance at $260 \mathrm{~nm}$ as a function of the temperature of the solution (Figure 1A,B). Being a tribasic acid $\left(\mathrm{p} K_{\mathrm{a} 1}=3.13, \mathrm{p} K_{\mathrm{a} 2}=4.76\right.$, and $\left.\mathrm{p} K_{\mathrm{a} 3}=6.40\right)$ whose dissociation constants are little influenced by temperature changes, ${ }^{25}$ citrate was the buffer of choice, enabling the evaluation of melting

Received: October 10, 2018

Revised: October 31, 2018

Published: November 1, 2018 

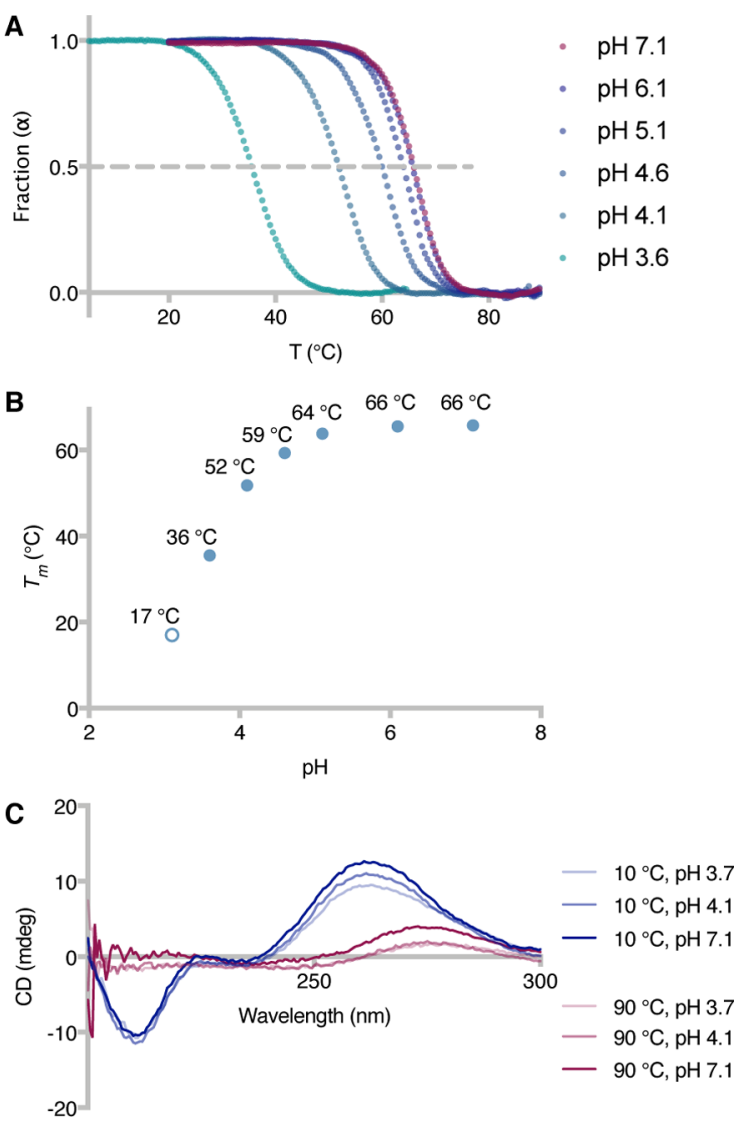

Figure 1. Modulation of RNA melting temperature by $\mathrm{pH}$ variations. (A) UV thermal melting curves of duplex 1 at different $\mathrm{pH}$ values (100 mM Na ${ }^{+}, 10 \mathrm{mM}$ citrate buffer, $\mathrm{pH}$ 3.6-7.1). Fraction of duplex RNA $(\alpha)^{32}$ vs temperature $(T): \alpha=1$ for double-stranded RNA, and $\alpha=0$ for single-stranded RNA. (B) Plot of duplex $1 T_{\mathrm{m}}$ vs solution $\mathrm{pH}$, as determined from panel $\mathrm{A}$. The $T_{\mathrm{m}}$ at $\mathrm{pH} 3.1$ was calculated from the first-derivative maximum of the thermal melting curves (see the Supporting Information). (C) Circular dichroism spectra of duplex 1 at different $\mathrm{pH}$ and temperature values.

point variations over a wide $\mathrm{pH}$ range and in the absence of buffer or temperature effects.

At $\mathrm{pH} 7.1$, duplex 1 exhibited a melting point of $65.7^{\circ} \mathrm{C}$, and minimal variations were observed when the $\mathrm{pH}$ of the solution was decreased to either 6.1 or $5.1\left(T_{\mathrm{m}}=65.5\right.$ or 63.8 ${ }^{\circ} \mathrm{C}$, respectively). On the other hand, significant changes in the duplex $T_{\mathrm{m}}$ were registered at $\mathrm{pH}<4.6$, with melting temperatures as low as 35.5 and $17.0{ }^{\circ} \mathrm{C}$ at $\mathrm{pH} 3.6$ and 3.1, respectively. In parallel, we measured the $\mathrm{CD}$ thermal melting curves of duplex 1 to verify that the observed variations were the result of double-stranded to single-stranded transitions, ruling out possible effects arising from changes in the UV absorption of the nucleobases upon protonation (Figure 1C and Figures S1A-C and S2). The $10{ }^{\circ} \mathrm{C} \mathrm{CD}$ spectra at $\mathrm{pH} 3.7$, 4.1, and 7.1 all exhibited a negative couplet and a positive couplet around 210 and $260 \mathrm{~nm}$, respectively, characteristic of double-stranded RNA structures. ${ }^{26}$ Upon heating, the $210 \mathrm{~nm}$ negative couplet progressively disappeared, together with a shift in the positive couplet maximum from 260 to $275 \mathrm{~nm}$ and a decrease in its intensity. These results confirm that denaturation of duplex 1 occurred upon heating over the entire $\mathrm{pH}$ range tested, and the melting temperatures determined by $\mathrm{CD}$ spectral changes were comparable with the data obtained in UV melting studies (Figure S1D). At $\mathrm{pH}$
3.7 and 4.6, the intensity of the CD signal was slightly lower than the spectra at higher $\mathrm{pH}$ values. This effect is presumably caused by nucleobase protonation, and we do not exclude the presence of base pairing arrangements other than the standard Watson-Crick type. ${ }^{21,22}$

Additionally, we assessed the general effect of $\mathrm{pH}$ variations on the melting temperature of two new 13mer RNA duplexes, differing from 1 with respect to their GC content [30.8\% GC content for duplex 2 and $69.2 \%$ GC content for duplex 3 (Table S1)]. As expected, changing the ratio of GC to AU base pairs affected the $T_{\mathrm{m}}$ values of both duplexes $\left(T_{\mathrm{m}}=50.3\right.$ and $75.3{ }^{\circ} \mathrm{C}$ at $\mathrm{pH} 7.1$ for duplexes 2 and 3, respectively), but the difference between the melting temperatures at $\mathrm{pH} 7.1$ and 3.6 $\left(\Delta T_{\mathrm{m}}\right)$ was independent of the duplex employed $\left[\Delta T_{\mathrm{m}}=30.2\right.$, 33.3, and $29.5^{\circ} \mathrm{C}$ for duplexes $1-3$, respectively (Table 1$\left.)\right]$.

Table 1. $T_{\mathrm{m}}$ and $\Delta T_{\mathrm{m}}$ Values of RNA Duplexes ${ }^{a}$

$\begin{array}{ccccc}\text { duplex } & \begin{array}{c}\mathrm{GC} \text { content } \\ (\%)\end{array} & \begin{array}{c}T_{\mathrm{m}}\left({ }^{\circ} \mathrm{C}\right) \text { at } \\ \mathrm{pH} 3.6\end{array} & \begin{array}{c}T_{\mathrm{m}}\left({ }^{\circ} \mathrm{C}\right) \text { at } \\ \mathrm{pH} 7.1\end{array} & \begin{array}{c}\Delta T_{\mathrm{m}} \\ \left({ }^{\circ} \mathrm{C}\right)\end{array} \\ \mathbf{1} & 53.8 & 35.5 \pm 0.5 & 65.7 \pm 0.3 & 30.2 \\ 2 & 30.8 & 17.0 \pm 0.0 & 50.3 \pm 0.3 & 33.3 \\ 3 & 69.2 & 45.8 \pm 0.3 & 75.3 \pm 0.3 & 29.5 \\ 4 & 50.0 & 56.5 \pm 0.5 & 84.2 \pm 0.3 & 27.7\end{array}$

${ }^{a}$ Values determined by UV thermal melting experiments ( \pm standard deviation). Conditions: $100 \mathrm{mM} \mathrm{Na}{ }^{+}, 10 \mathrm{mM}$ citrate buffer, pH 3.6 or 7.1 .

We next evaluated the potential of acidic $\mathrm{pH}$ values for the denaturation of duplexes that hardly melt under prebiotic conditions. Szostak and co-workers have previously shown that a 30mer RNA duplex containing four $2^{\prime}, 5^{\prime}$-linkages could be denatured at a temperature $15{ }^{\circ} \mathrm{C}$ lower than that of the corresponding naturally linked RNA duplex $[50.0 \%$ GC content for duplex 4 (Table S1) . $^{14}$ We thus measured the UV thermal curves of the fully $3^{\prime}, 5^{\prime}$-linked duplex 4 at $\mathrm{pH} 3.6$ and 7.1 and found a remarkable $27.7{ }^{\circ} \mathrm{C}$ drop in its melting temperature upon exposure to acidic conditions $\left[T_{\mathrm{m}}=56.5\right.$ and $84.2{ }^{\circ} \mathrm{C}$ at $\mathrm{pH} 3.6$ and 7.1 , respectively (Table 1 )]. These results demonstrate how the melting temperature of RNA duplexes could be significantly altered upon changes in the environmental $\mathrm{pH}$. Nevertheless, the prebiotic relevance of these results relies on whether moderate temperatures and low $\mathrm{pH}$ values would constitute an advantage over neutral $\mathrm{pH}$ and higher temperatures. A major concern in denaturing RNA duplexes is the increased risk of extensive phosphodiester bond cleavage. Furthermore, although less vulnerable than DNA, ${ }^{27-29}$ RNA might undergo a certain degree of depurination if exposed to acidic conditions. A direct comparison of the extent of degradation occurring during acidic or neutral RNA strand separation was thus needed. We investigated RNA depurination and phosphodiester bond cleavage following exposure to the conditions required to denature duplex 4 (either $\mathrm{pH} 3.5$ and $60{ }^{\circ} \mathrm{C}$ or $\mathrm{pH} 7.1$ and 90 ${ }^{\circ} \mathrm{C}$, as determined from the UV melting experiments). As a model for RNA depurination, we studied the degradation of adenosine by ${ }^{1} \mathrm{H}$ nuclear magnetic resonance (NMR) spectroscopy and found it to be highly stable under the acidic

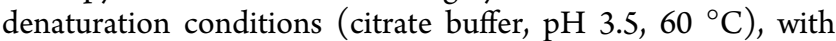
only $\sim 11 \%$ of depurination after heating for 17 days (Figure $2 \mathrm{~A}$ and Figure S3). By comparison, neutral denaturation conditions (citrate buffer, $\mathrm{pH} 7.1,90{ }^{\circ} \mathrm{C}$ ) resulted in $\sim 16 \%$ unspecific adenosine degradation after incubation for only 7 

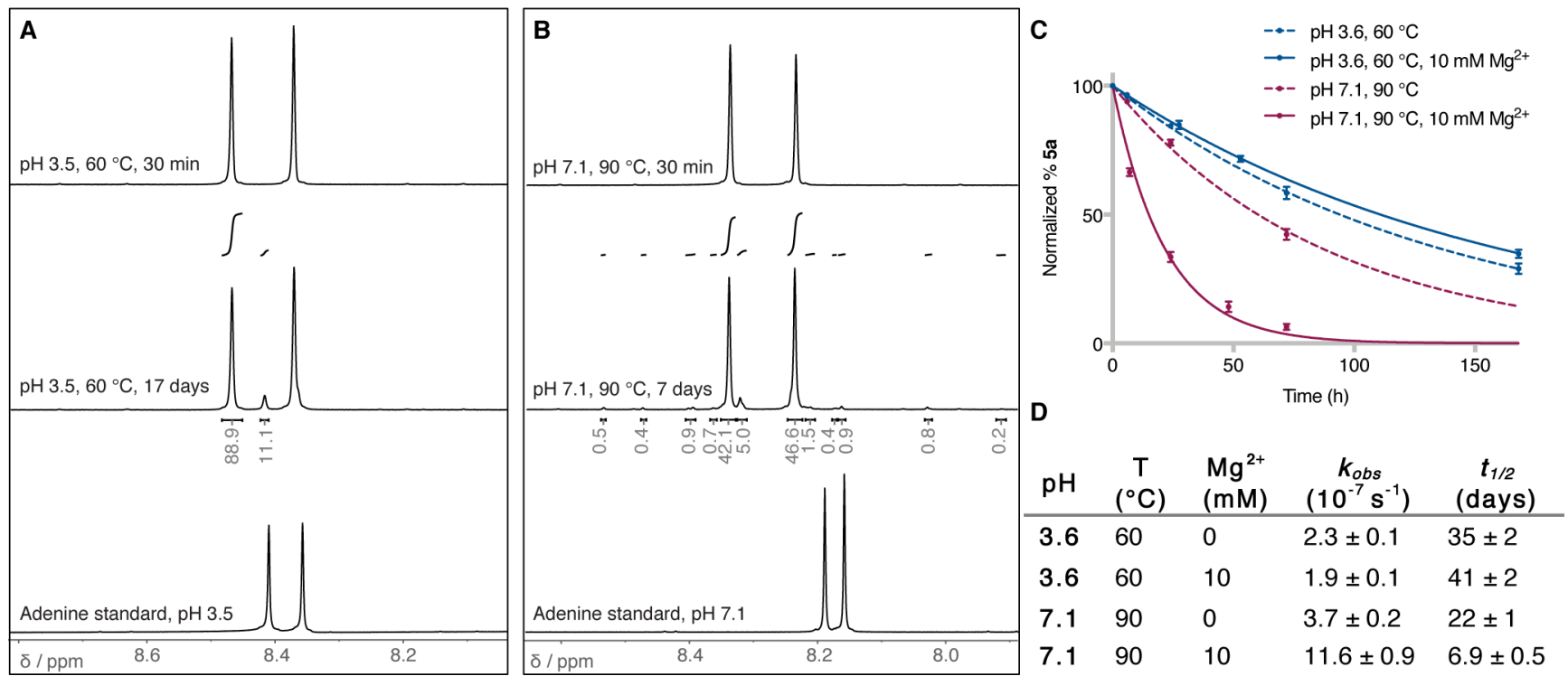

Figure 2. Degradation under acidic or neutral denaturation conditions. (A) ${ }^{1} \mathrm{H}$ NMR spectra [magnification of the $\mathrm{H}-\mathrm{C}(2)$ and $\mathrm{H}$-C $(8)$ region] showing the extent of adenosine degradation at $\mathrm{pH} 3.5$ and $60{ }^{\circ} \mathrm{C}$. (B) Same as panel A at pH 7.1 and $90{ }^{\circ} \mathrm{C}$. (C) Plot of the percentage of oligonucleotide $5 \mathrm{a}$ as a function of time, following incubation at either $\mathrm{pH} 3.5$ and $60{ }^{\circ} \mathrm{C}$ or $\mathrm{pH} 7.1$ and $90{ }^{\circ} \mathrm{C}$, in the presence or absence of $\mathrm{Mg}^{2+}$. (D) Average ( \pm standard deviation) hydrolysis rate constants $\left(k_{\mathrm{obs}}\right)$ and phosphodiester bond half-lives $\left(t_{1 / 2}\right)$, as calculated from panel C.

days (Figure 2B and Figure S4). In parallel, we estimated the extent of RNA backbone cleavage $e^{27,30}$ by monitoring the degradation of a FAM-labeled oligonucleotide [5a (Table S1)] by gel electrophoresis and fluorescence imaging. The average half-life of a phosphodiester bond $\left(t_{1 / 2}\right)$ was determined to be on the order of 35 days, when oligonucleotide $5 \mathbf{a}$ was incubated in citrate buffer at $\mathrm{pH} 3.6$ and $60{ }^{\circ} \mathrm{C}$ (Figure 2C,D and Figure S5). Remarkably, inclusion of $\mathrm{Mg}^{2+}$ in the reaction mixture did not accelerate the rate of phosphodiester cleavage $\left(t_{1 / 2}=41\right.$ days $)$. On the contrary, the $t_{1 / 2}$ dropped to 22 days when oligonucleotide 5a was heated at $90{ }^{\circ} \mathrm{C}$ at neutral $\mathrm{pH}$ (citrate buffer, $\mathrm{pH}$ 7.1) and further decreased to 7 days in the presence of the divalent metal catalyst. Altogether, these data suggest that an acidic environment would be advantageous both for decreasing the melting temperature required to denature RNA duplexes and for decreasing the degree of concomitant RNA degradation. This is particularly true when divalent metal ions are to be present in the environment, the hydrolytic catalytic activity of which has long been considered a major obstacle to the preservation of RNA integrity at neutral $\mathrm{pH}$. When these data are evaluated in the context of multiple cycles of non-enzymatic RNA replication, low $\mathrm{pH}$ values would therefore enable the separation of longer RNA duplexes with a lower degree of degradation, when compared to those characteristics under neutral conditions.

Lastly, we sought to establish reversibility in the system upon exposure to repetitive $\mathrm{pH}$ oscillation cycles. Oligonucleotide $\mathbf{5 a}$ and its complement $\mathbf{5 b}$ [50.0\% GC content for duplex 5 (Table S1)] were incubated in citrate buffer at $\mathrm{pH} 3.5$, and the duplex $T_{\mathrm{m}}$ was measured by means of $\mathrm{UV}$ thermal melting $\left[T_{\mathrm{m}}=47{ }^{\circ} \mathrm{C}\right.$ (Figure 3$\left.)\right]$. The $\mathrm{pH}$ of the solution was then increased to 6.8 by addition of Hepes buffer to the original mixture, and a new thermal curve was recorded $\left(T_{\mathrm{m}}=68{ }^{\circ} \mathrm{C}\right)$. The use of FAM-labeled oligonucleotide $5 \mathbf{a}$ enabled us to estimate that $0.8 \%$ of RNA strands had degraded as a result of the initial UV thermal melting measurement at low $\mathrm{pH}$. In parallel, we performed a control experiment, taking into account the duplex degradation and measuring the melting

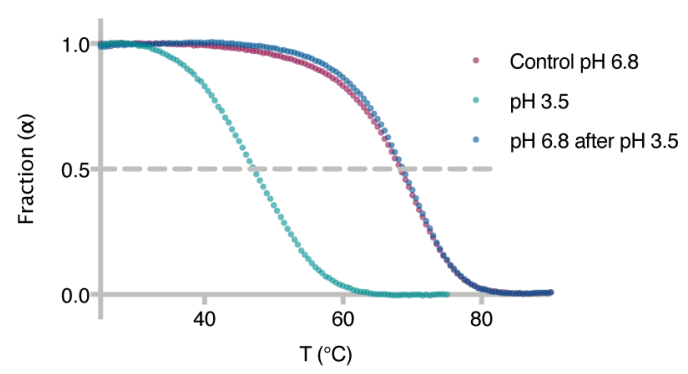

Figure 3. Reversibility in the system and absence of phosphodiester linkage isomerization. UV thermal melting curves of duplex $\mathbf{5}$ at $\mathrm{pH}$ $3.6\left(1 \mathrm{M} \mathrm{Na}^{+}, 10 \mathrm{mM}\right.$ citrate buffer $)$ and after adjusting the $\mathrm{pH}$ to 6.8 (1 $\mathrm{M} \mathrm{Na}^{+}, 10 \mathrm{mM}$ citrate buffer, $200 \mathrm{mM}$ Hepes buffer) and comparison with a control experiment at $\mathrm{pH} 6.8\left(1 \mathrm{M} \mathrm{Na}^{+}, 10 \mathrm{mM}\right.$ citrate buffer, $200 \mathrm{mM}$ Hepes buffer). $\alpha=1$ for double-stranded RNA, and $\alpha=0$ for single-stranded RNA.

temperature of duplex $\mathbf{5}$ only after adjusting the $\mathrm{pH}$ of the solution to neutral $\left(T_{\mathrm{m}}=68{ }^{\circ} \mathrm{C}\right)$. The $T_{\mathrm{m}}$ of duplex 5 at $\mathrm{pH}$ 6.8 was found to be identical in the two experiments, thus confirming the possibility of reverting the melting temperature of RNA by simply changing the $\mathrm{pH}$ of the solution. These results additionally rule out the chance of phosphodiester bond isomerization at acidic $\mathrm{pH},{ }^{31}$ as even a single $3^{\prime}, 5^{\prime}-$ to $2^{\prime}, 5^{\prime}$ linkage transition would have led to a measurable decrease in the duplex $T_{\mathrm{m}} \cdot{ }^{14,16}$

In conclusion, this report demonstrates the possibility of reversibly tuning the melting temperature of RNA duplexes by simply altering the $\mathrm{pH}$ of the environment. Our results support the relevance of $\mathrm{pH}$ oscillations on early Earth, suggesting a model in which low $\mathrm{pH}$ values and moderate temperatures would have enabled the separation of RNA strands previously considered impossible to melt in a prebiotic setting. At the same time, RNA integrity is better preserved under the conditions required for acid rather than neutral denaturation, especially when magnesium ions are needed for subsequent replication steps. Therefore, the non-enzymatic replication of RNA oligonucleotides might have benefitted from natural 
geochemical environments in which the combination of $\mathrm{pH}$ and temperature oscillations (as could have occurred in rock pores ${ }^{18}$ or by freeze-thaw cycles ${ }^{17}$ ) would have supported multiple cycles of RNA strand separation and reannealing. For instance, freezing of brine solutions results in a $\mathrm{pH}$ increase of $\leq 5$ units, the range of which apparently relies on nothing more than the initial $\mathrm{pH}$ of the solution. ${ }^{17}$ Thus, the transition from low $\mathrm{pH}$ and high temperature to high $\mathrm{pH}$ and low temperature required for RNA strand separation and replication cycles could have occurred in such natural environments. Nonetheless, RNA strand separation is only a small piece in the complex jigsaw that is the formation and evolution of RNA before the advent of life. Further investigations will be needed to provide explanations to the other many challenges in the field, including the possibility of preventing RNA strand invasion and inhibition in the course of multiple replication cycles. ${ }^{7}$

\section{ASSOCIATED CONTENT}

\section{S Supporting Information}

The Supporting Information is available free of charge on the ACS Publications website at DOI: 10.1021/acs.biochem.8b01080.

Materials and methods and supplementary figures and tables (PDF)

\section{AUTHOR INFORMATION}

\section{Corresponding Authors}

*E-mail: amariani@mrc-lmb.cam.ac.uk.

*E-mail: johns@mrc-lmb.cam.ac.uk.

ORCID

John D. Sutherland: 0000-0001-7099-4731

\section{Funding}

This work was supported by the Medical Research Council (Grant MC UP A024 1009) and a grant from the Simons Foundation (Grant 290362 to J.D.S.).

\section{Notes}

The authors declare no competing financial interest.

\section{ACKNOWLEDGMENTS}

The authors thank all J.D.S. group members for fruitful discussions.

\section{REFERENCES}

(1) Sutherland, J. D. (2016) The origin of life-out of the blue. Angew. Chem., Int. Ed. 55, 104-121.

(2) Patel, B. H., Percivalle, C., Ritson, D. J., Duffy, C. D., and Sutherland, J. D. (2015) Common origins of RNA, protein and lipid precursors in a cyanosulfidic protometabolism. Nat. Chem. 7, 301307.

(3) Stairs, S., Nikmal, A., Bučar, D.-K., Zheng, S.-L., Szostak, J. W., and Powner, M. W. (2017) Divergent prebiotic synthesis of pyrimidine and 8-oxo-purine ribonucleotides. Nat. Commun. 8, 15270.

(4) Gibard, C., Bhowmik, S., Karki, M., Kim, E.-K., and Krishnamurthy, R. (2017) Phosphorylation, oligomerization and self-assembly in water under potential prebiotic conditions. Nat. Chem. 10, 212-217.

(5) Ritson, D. J., Battilocchio, C., Ley, S. V., and Sutherland, J. D. (2018) Mimicking the surface and prebiotic chemistry of early Earth using flow chemistry. Nat. Commun. 9, 1821.

(6) Rimmer, P. B., Xu, J., Thompson, S. J., Gillen, E., Sutherland, J. D., and Queloz, D. (2018) The origin of RNA precursors on exoplanets. Sci. $A d v$. 4, No. eaar3302.
(7) Szostak, J. W. (2012) The eightfold path to non-enzymatic RNA replication. J. Syst. Chem. 3, 2.

(8) Weimann, B. J., Lohrmann, R., Orgel, L. E., Schneider-Bernloehr, H., and Sulston, J. E. (1968) Template-directed synthesis with

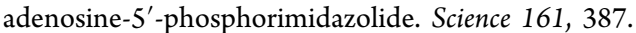

(9) Inoue, T., and Orgel, L. E. (1982) Oligomerization of (guanosine 5'-phosphor)-2-methylimidazolide on poly(C): An RNA polymerase model. J. Mol. Biol. 162, 201-217.

(10) Li, L., Prywes, N., Tam, C. P., O'Flaherty, D. K., Lelyveld, V. S., Izgu, E. C., Pal, A., and Szostak, J. W. (2017) Enhanced nonenzymatic RNA copying with 2 -aminoimidazole activated nucleotides. J. Am. Chem. Soc. 139, 1810-1813.

(11) Bowler, F. R., Chan, C. K. W., Duffy, C. D., Gerland, B., Islam, S., Powner, M. W., Sutherland, J. D., and Xu, J. (2013) Prebiotically plausible oligoribonucleotide ligation facilitated by chemoselective acetylation. Nat. Chem. 5, 383-389.

(12) Butzow, J. J., and Eichhorn, G. L. (1965) Interactions of metal ions with polynucleotides and related compounds. IV. Degradation of polyribonucleotides by zinc and other divalent metal ions. Biopolymers $3,95-107$.

(13) Giannaris, P. A., and Damha, M. J. (1993) Oligoribonucleotides containing 2',5'-phosphodiester linkages exhibit binding selectivity for 3', $5^{\prime}$-RNA over 3',5'-ssDNA. Nucleic Acids Res. 21, 4742-4749.

(14) Engelhart, A. E., Powner, M. W., and Szostak, J. W. (2013) Functional RNAs exhibit tolerance for non-heritable $2^{\prime}-5^{\prime}$ versus $3^{\prime}-5^{\prime}$ backbone heterogeneity. Nat. Chem. 5, 390-394.

(15) Usher, D. A., and McHale, A. H. (1976) Hydrolytic stability of helical RNA: a selective advantage for the natural $3^{\prime}, 5^{\prime}$-bond. Proc. Natl. Acad. Sci. U. S. A. 73, 1149-1153.

(16) Mariani, A., and Sutherland, J. D. (2017) Non-enzymatic RNA backbone proofreading through energy-dissipative recycling. Angew. Chem., Int. Ed. 56, 6563-6566.

(17) Takenaka, N., Tanaka, M., Okitsu, K., and Bandow, H. (2006) Rise in the $\mathrm{pH}$ of an unfrozen solution in ice due to the presence of $\mathrm{NaCl}$ and promotion of decomposition of gallic acids owing to a change in the pH. J. Phys. Chem. A 110, 10628-10632.

(18) Keil, L. M. R., Möller, F. M., Kieß, M., Kudella, P. W., and Mast, C. B. (2017) Proton gradients and $\mathrm{pH}$ oscillations emerge from heat flow at the microscale. Nat. Commun. 8, 1897.

(19) Bunville, L. G., and Geiduschek, E. P. (1960) DNA composition and stability to acid denaturation. Biochem. Biophys. Res. Commun. 2, 287-292.

(20) Bunville, L. G., Geiduschek, E. P., Rawitscher, M. A., and Sturtevant, J. M. (1965) Kinetics and equilibria in the acid denaturation of deoxyribonucleic acids from various sources. Biopolymers 3, 213-240.

(21) Courtois, Y., Fromageot, P., and Guschlbauer, W. (1968) Protonated polynucleotide structures. 3. An optical rotatory dispersion study of the protonation of DNA. Eur. J. Biochem. 6, 493-501.

(22) Segers-Nolten, G. M. J., Sijtsema, N. M., and Otto, C. (1997) Evidence for Hoogsteen GC base pairs in the proton-induced transition from right-handed to left-handed poly $(\mathrm{dG}-\mathrm{dC}) \cdot \operatorname{poly}(\mathrm{dG}-$ dC). Biochemistry 36, 13241-13247.

(23) Zhang, X., and Krishnamurthy, R. (2009) Mapping the landscape of potentially primordial informational oligomers: oligodipeptides tagged with orotic acid derivatives as recognition elements. Angew. Chem., Int. Ed. 48, 8124-8128.

(24) To the best of our knowledge, investigations of RNA have been limited to homopolymer complexes in the form of $\operatorname{poly}(\mathrm{C}) \cdot \operatorname{poly}(\mathrm{G})$ or poly $(\mathrm{C}) \cdot \operatorname{poly}(\mathrm{I})$ (which undergo the formation of triple-stranded helical structures upon protonation): (a) Thiele, D., and Guschlbauer, W. (1969) Polynucléotides protonés. VII. Transitions thermiques entre differents complexes de l'acide polyinosinique et de l'acide polycytidylique en milieu acide. Biopolymers $8,361-378$. (b) Thiele, D., and Guschlbauer, W. (1971) Protonated polynucleotide structures. IX. Disproportionation of $\operatorname{poly}(\mathrm{G}) \cdot \operatorname{poly}(\mathrm{C})$ in acid medium. Biopolymers 10,143-157. Other reports have focused on RNA mismatches stabilization following protonation: (c) Biała, E., 
and Strazewski, P. (2002) Internally mismatched RNA: pH and solvent dependence of the thermal unfolding of $\mathrm{tRNA}^{\text {Ala }}$ acceptor stem microhairpins. J. Am. Chem. Soc. 124, 3540-3545.

(25) Stoll, V. S., and Blanchard, J. S. (1990) Buffers: principles and practice. Methods Enzymol. 182, 24-38.

(26) Ranjbar, B., and Gill, P. (2009) Circular dichroism techniques: biomolecular and nanostructural analyses- a review. Chem. Biol. Drug Des. 74, 101-120.

(27) Zoltewicz, J. A., Clark, D. F., Sharpless, T. W., and Grahe, G. (1970) Kinetics and mechanism of the acid-catalyzed hydrolysis of some purine nucleosides. J. Am. Chem. Soc. 92, 1741-1750.

(28) Garrett, E. R., and Mehta, P. J. (1972) Solvolysis of adenine nucleosides. I. Effects of sugars and adenine substituents on acid solvolyses. J. Am. Chem. Soc. 94, 8532-8541.

(29) Lindahl, T. (1993) Instability and decay of the primary structure of DNA. Nature 362, 709-715.

(30) Kua, J., and Bada, J. L. (2011) Primordial ocean chemistry and its compatibility with the RNA world. Origins Life Evol. Biospheres 41, $553-558$.

(31) Oivanen, M., Kuusela, S., and Lönnberg, H. (1998) Kinetics and mechanisms for the cleavage and isomerization of the phosphodiester bonds of RNA by Brønsted acids and bases. Chem. Rev. 98, 961-990.

(32) Xu, J., Duffy, C. D., Chan, C. K. W., and Sutherland, J. D. (2014) Solid-phase synthesis and hybrization behavior of partially $2^{\prime} /$ 3'-o-acetylated RNA oligonucleotides. J. Org. Chem. 79, 3311-3326. 